\title{
Histological Evaluation of Early Graft Compatibility in Uapaca kirkiana Müell Arg. Scion/Stock Combinations
}

\author{
Simon A. Mng'omba ${ }^{1}$ and Elsa S. du Toit \\ Department of Plant Production and Soil Science, Faculty of Natural and \\ Agricultural Sciences, University of Pretoria 0002, Pretoria, Gauteng 27, \\ South Africa
}

Festus K. Akinnifesi
SADC-ICRAF, Agroforestry Programme, P.O. Box 30798, Lilongwe 3, Malawi

Helena M. Venter

CSIR NRE, Forestry Program, Tree Improvement, SERA Plant Propagation and Cultivation Technologies, P.O. Box 395, Pretoria 001, South Africa

Additional index words. Euphorbiaceae, graft abnormality, Miombo fruit, deposit

\begin{abstract}
Compatibility of scion and stock combinations in Uapaca kirkiana fruit trees has not been evaluated despite noticeable growth irregularities. The objectives of this study were to determine graft compatibility of scion/stock combinations and possible causes of graft incompatibility. Scion, stock, and graft union diameters were measured. Stem sections comprising the graft unions were immersed in formalin acetic acid and then washed in sterile water. These were transversely dissected across the unions and examined under using light microscope. There were considerable growth disorders at the unions, which included significant overgrowth of stocks and unions and constricted unions. There were cracks in the bark across the union in many graft combinations. Anatomic and histological studies showed accumulation of phenol deposits and necrotic tissues, and there was no continuity of vascular tissues above the union. There were also differences in proliferation of callus tissues among grafted partners. Continuity in wood and bark tissues below the unions supported growth of partially compatible partners, whereas isolated parenchymatous tissues at the union supported growth of incompatible partners. There were many necrotic tissues and unfilled areas above the union. Accumulation of phenolic and necrotic cell deposits, poor or a high level of callusing at the union, and possibly specific incompatibility reactions were implicated as the causes of graft incompatibility in $U$. kirkiana trees.
\end{abstract}

Uapaca kirkiana, an indigenous fruit tree of the Miombo ecozone, offers considerable scope for enhancing the nutritional and economic security of rural communities of southern Africa (Akinnifesi et al., 2006). Recent studies in Malawi and Zimbabwe showed that indigenous fruits, especially Uapaca, can reduce the probability of household poverty by $33 \%$ during a seasonal food shortage (Mithöfer et al., 2006). Moreover, it is widely preferred by small-holder farmers in southern Africa (Maghembe et al., 1998).

Germplasm of $U$. kirkiana trees from 16 provenances has been collected, characterized, and established in multilocational trials in five southern African countries (Kwesiga et al., 2000). These U. kirkiana tree provenances show wide genetic diversity and

Received for publication 29 Nov. 2006. Accepted for publication $11 \mathrm{Feb} .2007$.

Financial support from the Federal Ministry of Economic Cooperation (BMZ/GTZ), Germany, through the World Agroforestry Centre Southern Africa Regional Programme is acknowledged.

${ }^{1}$ To whom the reprint requests should be addressed; e-mail s23368854@tuks.co.za tree establishment was problematic. Grafting by the splice method has been the most promising method for $U$. kirkiana (Akinnifesi et al., 2004a, 2006). Moreover, rootstocks can impart desirable characters such as tree dwarfing, improved fruit traits (fruit sweetness, size, load, and color), and precocious fruiting (Ferree and Carlson, 1987; Usenik and Stampar, 2001; Webster, 2001).

Improved graft take $(80 \%)$ has been achieved in $U$. kirkiana trees when grafting was done by skilled grafters (Akinnifesi et al., 2004a). However, growth irregularities, possibly as a result of graft incompatibility have been observed in some grafted trees in the nursery and the field, and thus early or late rejection is suspected. Graft incompatibility occurring some years after grafting in normal growing trees constitutes a major concern in many grafted trees (Errea, 1998; Simons, 1987). Recent assessment of field survival of $U$. kirkiana grafted trees showed a declining trend starting from $100 \%$ at 6 months after field establishment to $67 \%$ at 33 months (Akinnifesi et al., 2007). Therefore, early evaluation of scion/stock combinations is important for successful orchard establishment and productivity. However, there is no scientific research devoted to graft incompatibility in $U$. kirkiana trees to date. The objectives of this study were to determine graft compatibility of different scion and stock combinations, and the possible causes of scion and stock incompatibility in U. kirkiana trees.

\section{Materials and Methods}

A Uapaca nursery stock (1 year after grafting) at SADC-ICRAF Makoka Research Station in Malawi (alt., $1029 \mathrm{~m}$ asl; lat., $15^{\circ} 30^{\prime} \mathrm{S}$; long., $35^{\circ} 15^{\prime} \mathrm{E}$ ) was used for this study. This site has a total annual rainfall of 560 to $1600 \mathrm{~mm}$, and the temperature varies between 16 and $32{ }^{\circ} \mathrm{C}$ (Akinnifesi et al., 2004b). Stem diameters of scions, stocks, and graft unions were measured using a pair of calipers. Bark thickness for both scions and stocks was also measured.

Ten grafts of $U$. kirkiana trees, grafted by the splice method, were randomly selected. Table 1 shows the identity, sources and codes of scions and stocks selected. Samples were collected by cutting $\approx 4$ to $5 \mathrm{~cm}$ below and above the scion/stock union. Stem sections were immediately immersed in formalin acetic acid (5\% formalin, 5\% acetic acid, and $90 \%$ ethanol) and later rinsed in sterile water to remove the acid. Samples were then mounted on a slide microtome stage (model E. Leitz, Wetzlar 17815, Germany) by freezing $\mathrm{CO}_{2}$ gas. Thin-layer transverse sections $(10 \mu \mathrm{m})$ were cut at a right angle to the union and then mounted onto microscope slides. Specimens were viewed under a light microscope (Olympus microscopy model: ach 1x, SZX7, Germany), connected to a digital camera (Olympus, Japan), and microphotographs of the union interfaces were taken.

Visual scoring for graft compatibility included a visible union line in the bark and 
wood where 1 is visible, 2 is faint, 3 is very faint, and 4 is absent; browning intensity of deposits at the union interface where 1 is high, 2 is medium, 3 is low, and 4 is absent; and callus proliferation where 1 is high, 2 is medium, 3 is low, and 4 is absent. Visual scores were converted to percentages $(0 \%$ to $25 \%$, absent/very low; $26 \%$ to $50 \%$, very faint/low; $51 \%$ to $75 \%$, medium/faint; $76 \%$ to $100 \%$, high).

Data on diameters of scions, stocks and unions, and bark thicknesses of scions and stocks were arranged in a completely randomized design and then subjected to analysis of variance. Data on visual scores were analyzed using correspondence analysis in GenStat (Rothamsted Exp. Sta.). Histological variables (union line, callus proliferation, and deposit intensity) were used to discriminate the compatible from the incompatible combinations [adapted from Ermel et al. (1995)].

\section{Results and Discussion}

There was an increase in stem diameter at the unions compared with the scions and stocks. However, there were no significant differences in diameter between the scions and stocks (Table 2). Results agree with the findings of Tshokoeva and Tsonev (1995), who reported marginal differences between scion and stock diameters in grafted apricot trees, but a significant increase in diameter at the union. An increase in stem diameter at the union could be attributed to accumulation of metabolites (presumably phenols and carbohydrates) as a result of partial cambium continuity at the union. Errea (1998) reported that translocation problems caused accumulation of some compounds. Moreover, high levels of calluses forming into the undifferentiated parenchymatous cells could also cause the union to swell. Rootstocks had significantly thicker bark than scions, and this could be attributed to differences in growth and callusing rates after grafting (Table 2).

Fig. 1A shows a good level of callusing and healing at the union of the MW26/22 combination. Fig. 1B (MW1/61) shows an increase in union diameter and cracking of the bark. Generally, many U. kirkiana trees have cracks in bark running almost vertical to the tree axis and this can be attributed to a genotypic trait. However, horizontal cracks across the union could be implicated in graft incompatibility.

Andrews and Marquez (1993) reported that hormonal imbalances between stocks and scions are involved in graft incompatibility. Furthermore, flavonoids (phenolics) are known to inhibit callus growth whereas auxins control callus formation (Andrews and Marquez, 1993; Errea et al., 1994b). DeCooman et al. (1996) reported accumulation of $\rho$-coumaric acid (phenolic compound) in less compatible Eucalyptus gunnii graft combinations, and Usenik et al. (2006) found high levels of $\rho$-coumaric acids above the union of incompatible apricot graft combinations.

Table 1. Tree identification (ID) of selected Uapaca kirkiana stocks and scions from different districts and locations on landscape (natural forest or cultivated field) in Malawi.

\begin{tabular}{lllll}
\hline Tree ID & \multicolumn{1}{c}{ Accession name } & District & Landscape & \multicolumn{1}{c}{ Fruit trait } \\
\hline MW1 & ICR02 NkhumbaMW1 & Zomba & Forest & Sweetness \\
MW2 & ICR02 KanyotaMW2 & Zomba & Forest & Sweetness \\
MW7 & ICR02 MalemiaMW7 & Zomba & Forest & Sweetness \\
MW10 & ICR02 MalemiaMW10 & Zomba & Forest & Sweetness \\
MW12 & ICR02 SitolaMW12 & Zomba & Forest & Sweetness \\
MW13 & ICR02 SitolaMW13 & Zomba & Forest & Sweetness, size \\
MW22 & ICR02 ElsonMW22 & Dedza & Forest & Sweetness \\
MW26 & ICR02 HardwickMW26 & Dedza & Field & Sweetness, load, size \\
MW28 & ICR02 HamiyoniMW28 & Dedza & Field & Sweetness \\
MW32 & ICR02 YesayaMW32 & Dedza & Forest & Sweetness, size \\
MW49 & ICR02 NkhumbaMW49 & Phalombe & Forest & Sweetness, fruit load \\
MW57 & ICR02 NkhumbaMW57 & Phalombe & Forest & Sweetness, fruit early \\
MW57 & ICR02 YesayaMW57 & Dedza & Forest & Sweetness \\
MW61 & ICR02 MigowiMW61 & Phalombe & Forest & Sweetness, fruit early \\
MW71 & ICR02 NkhumbaMW71 & Phalombe & Forest & Sweetness, fruit load \\
MW84 & ICR02 NazombeMW84 & Phalombe & Forest & Sweetness \\
\hline
\end{tabular}

Table 2. Scion, stock, and graft union diameters, and bark thickness of Uapaca kirkiana fruit trees pooled together (1 year after grafting).

\begin{tabular}{lcc}
\hline Plant parts & Stem diameter $(\mathrm{cm})$ & Bark thickness $(\mathrm{cm})$ \\
\hline Scion & $1.10 \mathrm{~b}^{\mathrm{z}}$ & $0.18 \mathrm{~b}$ \\
Stock & $1.21 \mathrm{~b}$ & $0.25 \mathrm{a}$ \\
Unions & $1.50 \mathrm{a}$ & $-\mathrm{y}$ \\
Coefficient of variation (\%) & 14.3 & 20.5 \\
LSD $_{0.01}$ & 0.22 & 0.06 \\
\hline
\end{tabular}

${ }^{\mathrm{z}}$ Mean separation by LSD within a column at $P \leq 0.01$.

yot measured.

Measurements were taken $\approx 5 \mathrm{~mm}$ below and above the union and the bark.
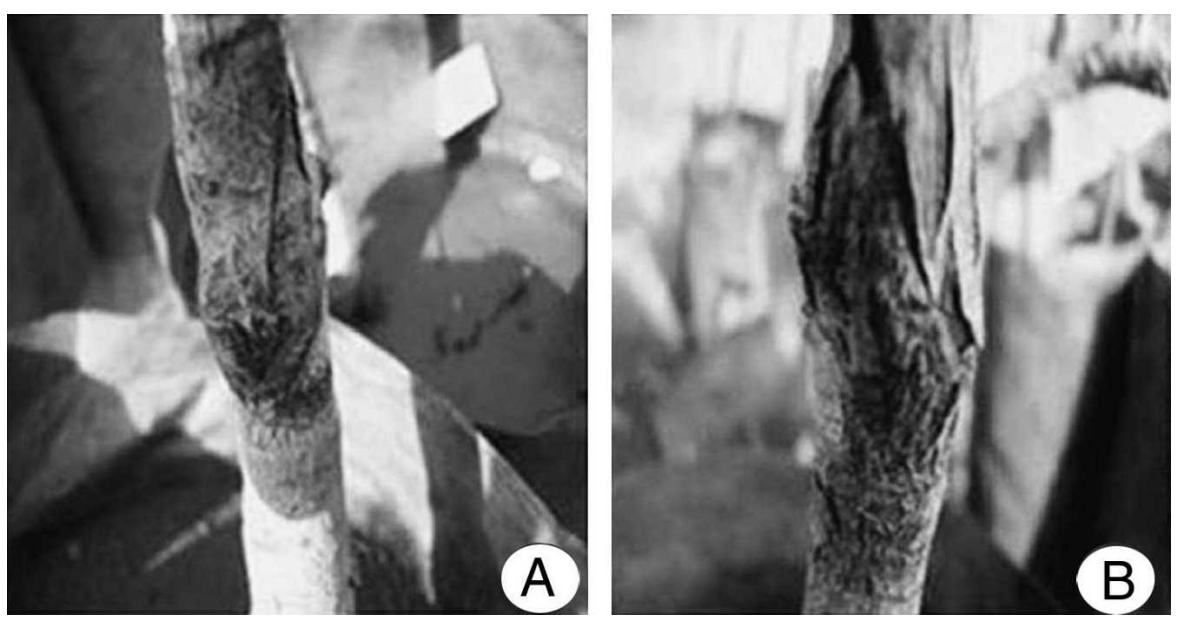

Fig. 1. Morphology of Uapaca kirkiana graft unions. (A) AlenaHardwickMW26 (scion) on HardwickElsoniMW22. (B) NkhumbaMW1 (scion) on MigowiMW61. Note the bark cracking at the union.

According to Akinnifesi et al. (2004a), matching the cambial cells between scion and stock has been a challenge in grafting $U$. kirkiana trees because scions are always thicker than the stocks. Therefore, correct matching depends on selecting scions and stocks with almost similar stem diameter and bark thickness. This improves proximity of vascular tissues of the scions and stocks. In this trial, bark thickness at the union was not measured, but could be a factor contributing to an increase in union diameter. This is because the presence of nonfunctional tissues can increase the union diameter. Simons and Chu (1981) reported an overgrowth of the union resulting from radial growth of vascular tissues.
Fig. 2 illustrates the external view and longitudinal section of the unions. There are variations in the level of callus proliferation and union line visibility. Fig. 2A shows a poor level of callusing (external view) and a visible union line at the union interface. Fig. $2 \mathrm{~B}$ shows continuity in the bark and wood tissues below the union, and this is termed a "partial" graft union (Ünal, 1995.) Graft partners with a partial union showed a good level of callusing at the union (external view and longitudinal section). Therefore, a poor graft union could be associated with a low level of callusing, as shown in Fig. 2A.

Fig. 3 shows incompatible (Fig. 3A) and partially compatible (Fig. 3B) unions between $U$. kirkiana partners. MW84 (Nazombe) on 

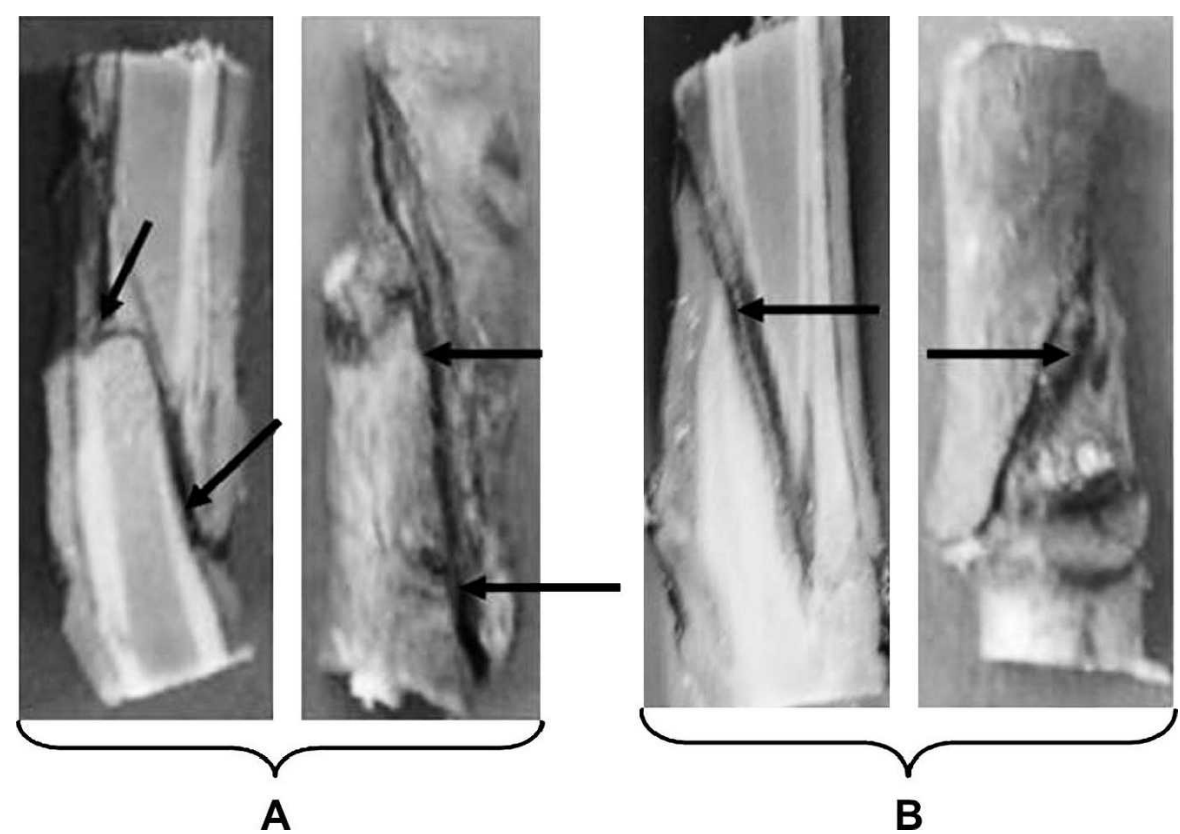

Fig. 2. Longitudinal sections of the graft unions of Uapaca kirkiana trees. (A) Note the poor level of callusing at the union. (B) Note the good level of callusing at the union. Arrows indicate necrotic tissues for the longitudinal sections and differences in callus proliferation for the external view.
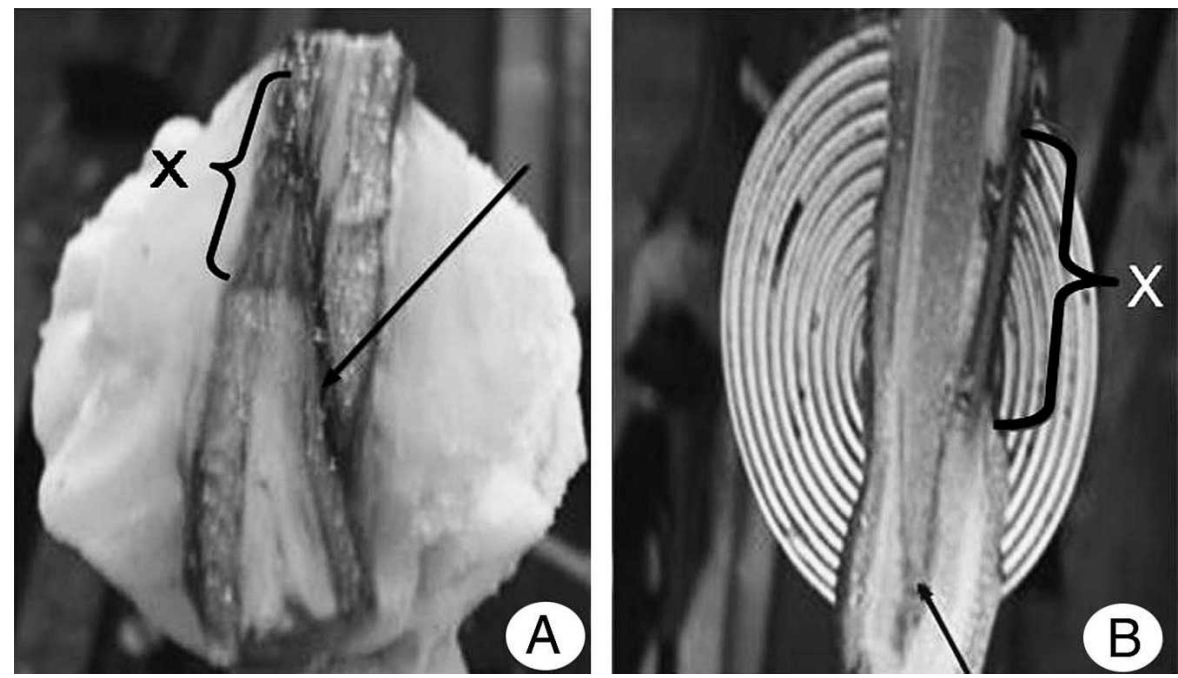

Fig. 3. Uapaca kirkiana scion and stock combination illustrates (A) a visible line between the scion (NazombeMW84) and stock (NkhumbaMW57), and (B) a faint line between the scion (AlenaHardwickMW26) and stock (HardwickElesonMW22). "X" indicates necrosis of bark and tissues above the union and arrows indicate visible union lines.

MW57 (Nkhumba) stock shows incompatibility, attributed to wide unfilled areas (no continuity in the bark and wood tissues) at the union interface and the necrosis of bark and wood tissues above the union (Fig. 3A). Survival of such a combination could be attributed to the presence of some portions of undifferentiated (parenchymal) tissues. Errea et al. (1994a) reported the presence of some parenchymal tissues that caused weak unions in incompatible Prunus species. In this trial, bark tissues above the union were heavily stained and necrotic. The area of stained and necrotic tissues was smaller in partial compatible partners (Fig. 3A) than in incompatible partners (Fig. 3B).
Fig. 4 shows that MW26/22, MW26/26, and MW7/10 combinations were closely associated with each other using correspondence analysis. Morphologically, these combinations showed partial compatibility, whereas those at the right and upper quadrant were incompatible. However, it is difficult to interpret anatomic and histological studies based on longitudinal sections because of variability induced during grafting and variations in incompatibility symptoms (Ermel et al., 1995). Moreover, there are problems in identifying the right statistical procedure to separate compatible combinations from incompatible combinations. Errea et al. (2001) used contingency tables, but no statistical differences were found and there was reduction in validity of the test. Correspondence analysis seems to offer a better procedure to discriminate compatible combinations from incompatible combinations (Ermel et al., 1997). It is based on $\chi^{2}$ transformation and produces dimensions that represent the $\chi^{2}$ distances (Lebart et al., 1984). In this trial, the principal inertias $(\lambda)$ were $0.06(79.5 \%)$ and $0.14(18.0 \%)$ at one and two dimensions respectively. Therefore, a two-dimensional correspondence analysis was appropriate because it represented $97.5 \%$ of the profiles (Fig. 4).

Fig. 5 shows a common trend for callus proliferation at the unions observed using a light microscope. Callus cells were prolific below the union, where a good union was formed. Tissues above the union were necrotic and highly stained, and hence there was no continuity in the bark and wood. Observations showed that $U$. kirkiana plants exude a lot of secondary metabolites (phenols) in response to wounding. Hamisy (2004) reported high levels of phenols in $U$. kirkiana leaves during DNA extraction. Therefore, it is suspected that phenols could play a role in graft incompatibility of $U$. kirkiana trees. According to Errea (1998), phenols have been implicated in union formation processes because they can cause insufficient callus proliferation, cell necrosis, and metabolic interactions. These ultimately cause disorder and damage at the union.

Fig. 5A shows a high deposit accumulation in an incompatible combination. There are many unfilled areas and necrotic layers above the union. Fig. 5B, C shows a high deposit accumulation above and at the union. Errea et al. (1994b) reported that high phenol accumulation occurs at the union of less compatible combinations. Fig. 5C shows that prolific callus cells make the union line narrow. According to Ermel et al. (1997), cell necrosis and discontinuity of vascular connections at the union are the main indicators of incompatibility. Gebhardt and Feucht (1982) reported a high quantity of phenols above the union as a cause of graft incompatibility in Prunus species. Errea (1998) and Considine (1983) reported that some incompatible partners may grow without any external indication of incompatibility, but the presence of phenols accumulating at the union serves as an indicator of problems in graft combinations. However, graft incompatibility has been attributed to other factors, including hormones, peroxidases, lack of plasmodesmata formation and vascular tissue connection, RNA and indole-3acetic acid (IAA) transport, and inherent incompatibility at the cellular level (Andrews and Marquez, 1993; Usenik et al., 2006).

Fig. 6B shows the presence of phenolic deposits below the union of a compatible combination. Callus tissues were breaking up the deposits from the lower side of the union (Fig. 6A), and small pockets of phenolic deposits were observed. Errea et al. (1994) reported that phenols prevent cambial 


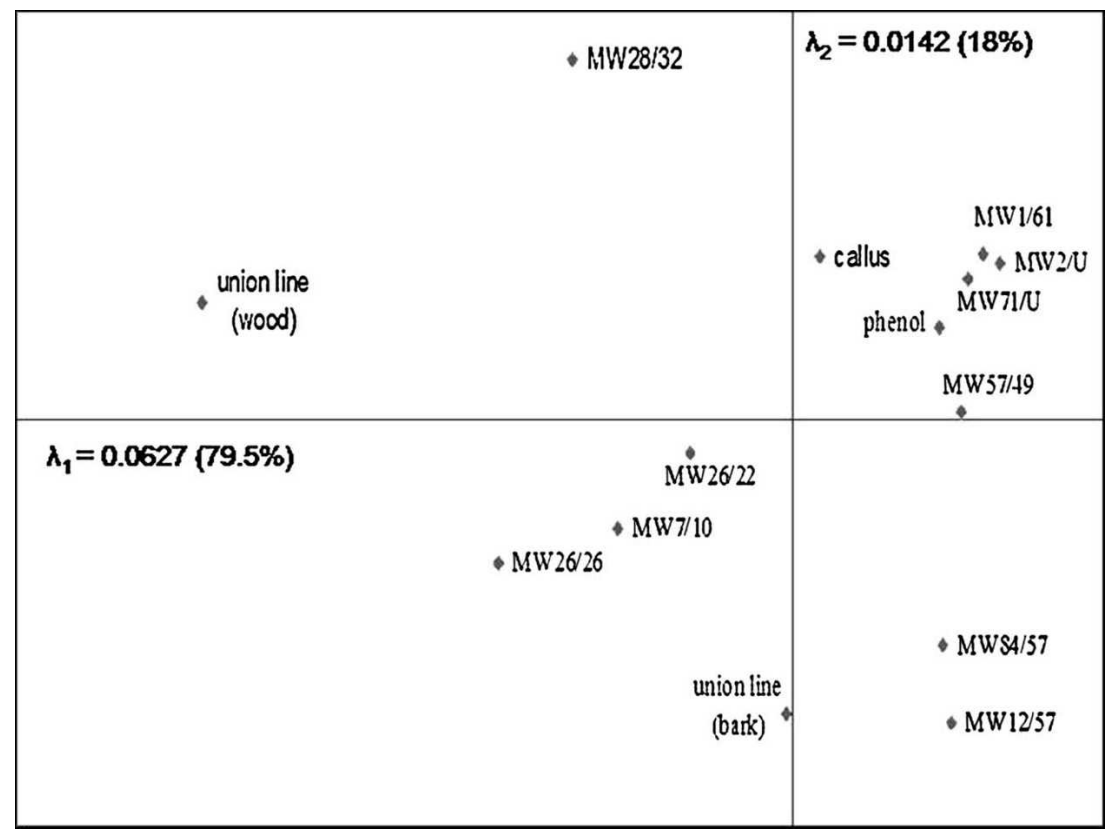

Fig. 4. A two-dimensional correspondence analysis of the distribution and association of different grafted Uapaca kirkiana trees with respect to union line in the bark and wood, presence of phenols, and callus proliferation at the union. $\mathrm{U}$, unknown stock.
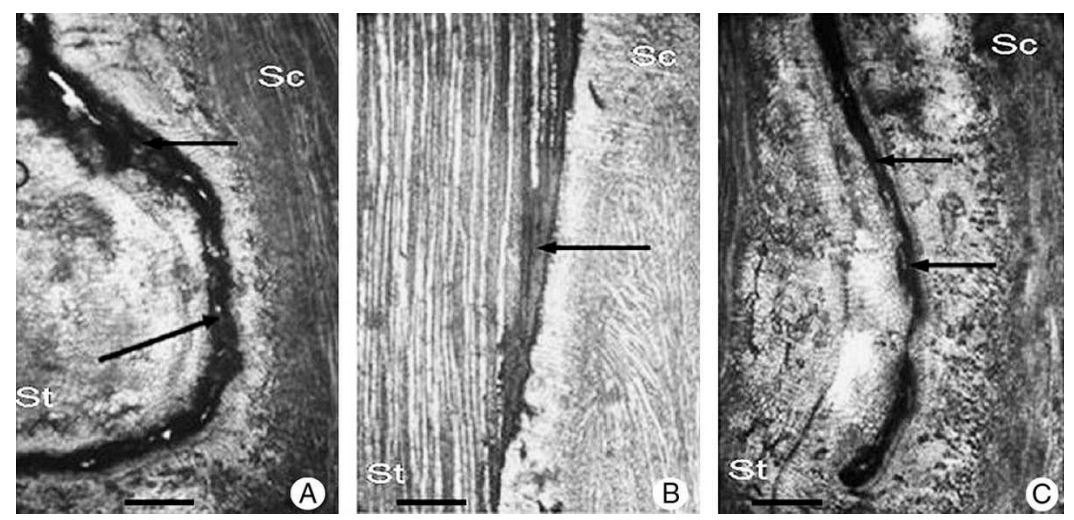

Fig. 5. Presence of deposits (phenols) at the union interface of Uapaca kirkiana scions and stocks. (A) Incompatible partners with high levels of deposits. (B) Partial compatible combination with high deposit accumulation above and at the union. (C) Callus tissues breaking up phenols below the union area. Arrows indicate deposits. St, stock; Sc, scion. Bar $=5 \mu \mathrm{m}$.
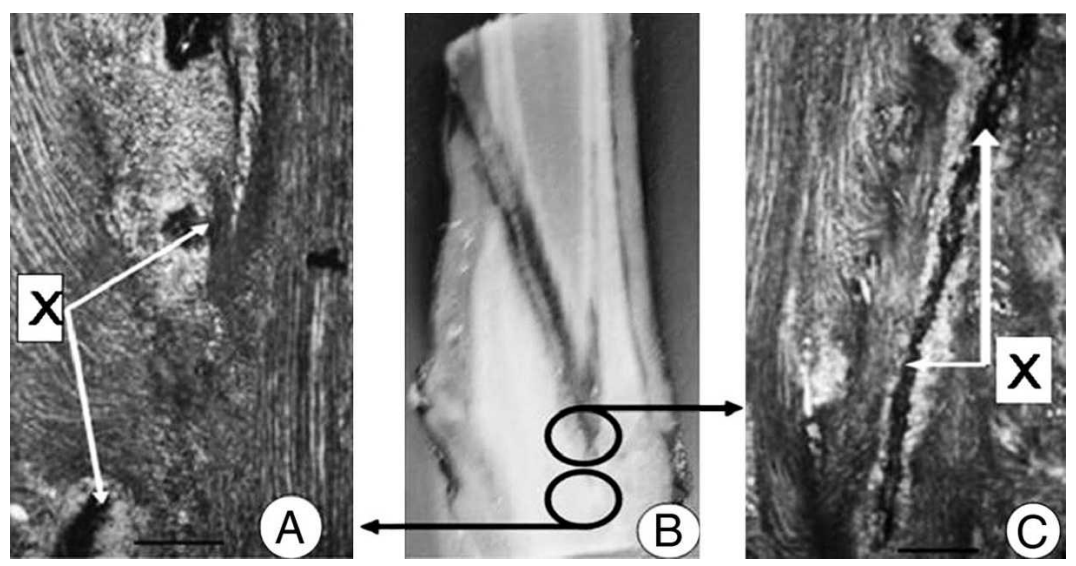

Fig. 6. Sections below the union of a compatible MW26/22 Uapaca kirkiana combination. (A) A low phenol accumulation. (B) Scion/stock combination. (C) An increase in phenol accumulation. " $X$ " indicates pockets of deposits (phenols) in section A and an accumulation of deposits along the union line in section C. Bar $=5 \mu \mathrm{m}$. connection continuity. Therefore, the presence of necrotic tissues and phenolic deposits are implicated in graft incompatibility of $U$. kirkiana trees. Fig. 6C shows a narrow line of deposits, and this indicates a gradual increase in quantity of deposits from the lower to the upper part of the union.

Hartmann et al. (1990) reported that maintaining a film of water at the union during grafting is necessary for callus formation. This water could possibly dilute some phenols, especially water-soluble phenols, as they accumulate below the union. This could aid in breaking up deposits (phenols) by the prolific callus cells. Consequently, grafted partners are able to establish cambial continuity. However, such a hypothesis needs to be tested further for U. kirkiana.

Graft set in $U$. kirkiana trees during the November to December period $(63 \%)$ was better than those set in June (30\%) (Akinnifesi et al., 2004a), and this suggests seasonality in phenol accumulation. Tree samples used in this trial were grafted during the months of June, August, and early October. Therefore, time of grafting of $U$. kirkiana trees could play a role in graft compatibility.

\section{Conclusion}

Indicators of graft incompatibility in $U$. kirkiana trees include growth irregularities at the union, presence of necrotic tissues, and phenolic deposits at the union interface. Such findings confirm existence of graft union problems, although these trees were surviving in the nursery. However, phenol quantification and identification are needed to support the role of phenols in graft compatibility. For graft-incompatible partners, portions of parenchymal tissues supported the graft unions. MW26/26, MW26/22, MW7/10 graft combinations were partially compatible in this study.

\section{Literature Cited}

Akinnifesi, F.K., O. Ajayi, G. Sileshi, F.R Kwesiga, C. Ham, J. Mhango, I. Kadzere, T. Chilanga, A. Mkonda, and P. Matakala. 2007. Creating opportunities for domesticating and commercializing miombo indigenous fruit trees in southern Africa. In: F.K. Akinnifesi, G. Sileshi, O. Ajayi, Z. Tchoundjeu and P. Matakala (eds). Indigenous fruit trees in the tropics: Domestication, utilization and commercialization. CABI publishing (in press).

Akinnifesi, F.K., T. Chilanga, A. Mkonda, and F. Kwesiga. 2004a. Domestication of Uapaca kirkiana in southern Africa: A preliminary evaluation of provenances in Malawi and Zambia, p. 85-92. In: M.R. Rao and F.R. Kwesiga (eds.). Proceedings of the Regional Agroforestry Conference on Agroforestry Impacts on Livelihood in Southern Africa: Putting research into practice. World Agroforestry Ctr., Nairobi, Kenya.

Akinnifesi, F.K., F. Kwesiga, J. Mhango, T. Chilanga, A. Mkonda, C.A.C. Kadu, I. Kadzere, D. Mithöfer, J.D.K. Saka, G. Sileshi, T. Ramadhani, and P. Dhliwayo. 2006. Towards the development of Miombo fruit trees as commercial tree crops in southern Africa. Forest, Trees Livelihood 16:103-121. 
Akinnifesi, F.K., F.R. Kwesiga, J. Mhango, A. Mkonda, T. Chilanga, and R. Swai. 2004b. Domesticating priority for Miombo indigenous fruit trees as a promising livelihood option for small-holder farmers in southern Africa. Acta Hort. 632:15-30.

Andrews, P.K. and C.S. Marquez. 1993. Graft incompatibility, p. 183-232. In: J. Janick (ed.). Horticultural reviews. Vol. 15. Wiley, New York.

Considine, J.A. 1983. Concepts and practice of use of plant growth regulating chemicals in viticulture, p. 89-183. In: L.G. Nickell (ed.). Plant growth regulating chemicals. Vol. 1. CRC Press, Boca Raton, Fla.

DeCooman, L., E. Everaert, P. Curir, and M. Dolci. 1996. The possible role of phenolics in incompatibility expression in Eucalyptus gunnii micrografts. Phytochem. Anal. 7:92-96.

Ermel, F.F., A.M. Catesson, and J.L. Poessel. 1995. Early histological diagnosis of apricot/peach $\times$ almond graft incompatibility: Statistical analysis of data from 5-month-old grafts. Acta Hort. 384:497-503.

Ermel, F.F., J.L. Poessel, M. Faurobert, and A.M. Catesson. 1997. Early scion/stock junction in compatible and incompatible pear/pear and pear/quince grafts: A histo-cytological study. Ann. Bot. (Lond.) 79:505-515.

Errea, P. 1998. Implications of phenolic compounds in graft incompatibility in fruit tree species. Sci. Hort. 74:195-205.

Errea, P., A. Felipe, and M. Herrero. 1994a. Graft establishment between compatible and incompatible Prunus spp. J. Expt. Bot. 272:393-401.

Errea, P., A. Felipe, D. Treutter, and W. Feucht. 1994b. Flavanol accumulation in apricot grafts as a response to incompatibility stress. Acta Hort. 381:498-501.

Errea, P., L. Garay, and J.A. Marin. 2001. Early detection of graft incompatibility in apricot (Prunus armeniaca) using in vitro techniques. Physiol. Plant. 112:135-141.

Ferree, D.C. and R.F. Carlson. 1987. Apple rootstocks, p. 107-143. In: R.C. Rom and R.F. Carlson (eds.). Rootstocks for fruit crops. Wiley, New York.

Gebhardt, K. and W. Feucht. 1982. Polyphenol changes at the union of Prunus avium/Prunus cerasus grafts. J. Hort. Sci. 57:253-258.

Hamisy, W.C. 2004. Promotion of effective conservation and sustainable utilization of Uapaca kirkiana (Müell Arg.). Project report. ICRAF Nairobi, Kenya.

Hartmann, H.T., D.E. Kester, and F.T. Davies, Jr. 1990. Plant production, principles and practices. 5th ed. Prentice-Hall, Englewood Cliffs, N.J.

Kwesiga, F., F.K. Akinnifesi, T. Ramadhani, I. Kadzere, and J. Saka. 2000. Domestication of indigenous fruit trees of the Miombo in southern Africa, p. 8-24. In: E.M. Shumba, E. Lusepani, and R. Hangula (eds.). The domestication and commercialization of indigenous fruit trees in the SADC region SADC Tree Seed Ctr. Network, Harare, Zimbabwe.

Lebart, L., A. Morineau, and K.M. Warwick. 1984. Multivariate descriptive statistical analysis. Correspondence analysis and related techniques for large matrices. Wiley, New York.

Maghembe, J.A., A.J. Simons, F. Kwesiga, and M. Rarieya. 1998. Selecting indigenous trees for domestication in southern Africa, p. 1-39. ICRAF, Nairobi, Kenya.
Mhango, J.L., F.K. Akinnifesi, and T.G. Chilanga. 2000. Vegetative propagation of Uapaca kirkiana (Muell Arg.) in Malawi. In: Annual report, Jan.-Dec. 2000: Achievements in agroforestry research and development in Malawi. ICRAF, Zomba, Malawi.

Mithöfer, D., H. Waibel, and F.K. Akinnifesi. 2006. The role of food from natural resources in reducing vulnerability to poverty: A case study from Zimbabwe. Presented at the 26th Conf. IAAE, Queensland, Australia, 12-26 Aug.

Simons, R.K. 1987. Compatibility and stock-scion interactions as related to dwarfing, p. 79-106. In: R.C. Rom and R.F. Carlson (eds.). Rootstocks for fruit crops, Wiley, New York.

Simons, R.K. and M.C. Chu. 1981. Morphological and anatomical characteristics of graft unions in apple trees on dwarfing rootstocks. Acta Hort. 114:198-199.

Tshokoeva, M.D. and R.V. Tsonev. 1995. Compatibility of rootstock and scions in apricots trees. Acta Hort. 384:471-476.

Ünal, A. 1995. Anatomy of the graft union and degree of incompatibility of some apricot varieties budded onto plum, almond and peach seedlings. Acta Hort. 384:493-496.

Usenik, V., B. Krška, M. Vičan, and F. Štampar. 2006. Early detection of graft incompatibility apricots (Prunus amerniaca L) using phenol analyses. Sci. Hort. 109:332-338.

Usenik, V. and F. Stampar. 2001. Different rootstocks for cherries: Influence on polyphenol content and graft incompatibility. Acta Hort. 557:175-179.

Webster, A.D. 2001. Rootstocks for temperate fruit crops: Current uses, future potential and alternative strategies. Acta Hort. 557:25-34. 